\title{
(E)-2-Nonenal determination in brazilian beers using headspace solid-phase microextraction and gas chromatographic coupled mass spectrometry (HS-SPME-GC-MS)
}

\author{
Determinação de (E)-2-nonenal em cervejas brasileiras utilizando microextração em fase \\ sólida do headspace e cromatografia gasosa acoplada a espectrometria de massas
}

\author{
Rodrigo SCHERER ${ }^{1}$, Roger WAGNER ${ }^{1}$, Cláudia Hoffmann KOWALSKI ${ }^{1}$, Helena Teixeira GODOY ${ }^{1 *}$
}

\begin{abstract}
(E)-2-nonenal is considered an important off-flavor of beer, related to the flavor of beer staling. In this study, a new method for determination of (E)-2-nonenal in beer using headspace solid-phase microextraction and gas chromatographic coupled mass spectrometry (HS-SPME-GCMS) was developed and applied in Brazilian beer samples. The extractions were carried out in CAR-PDMS (carboxen-polydimethylsiloxane) fiber and the best results were found with 15 minutes of equilibrium and 90 minutes of extraction at $50{ }^{\circ} \mathrm{C}$. The method was linear in the range from 0.02 to $4.0 \mu \mathrm{g} . \mathrm{L}^{-1}$ with correlation coefficient of 0.9994 . The limits of detection and quantification were 0.01 and $0.02 \mu \mathrm{g} . \mathrm{L}^{-1}$, respectively. $96.5 \%$ of recovery and $4 \%$ precision (RSD) were obtained in the fortification of beer samples with $2.0 \mu \mathrm{g} . \mathrm{L}^{-1}$ of $(E)-2$-nonenal. The developed method proved to be simple, efficient and highly sensitive to the determination of this analyte being easily applied in the quality control of the brewery. (E)-2-nonenal was found in all beer samples analyzed with levels between 0.17 and $0.42 \mu \mathrm{g} . \mathrm{L}^{-1}$.

Keywords: beer; (E)-2-nonenal; off-flavor; volatile compound; SPME.
\end{abstract}

\section{Resumo}

O (E)-2-nonenal é considerado um importante off-flavor da cerveja, sendo relacionado ao sabor de cerveja envelhecida. Neste estudo, um novo método para determinação de (E)-2-nonenal em cerveja usando microextração em fase sólida do headspace e cromatografia a gás acoplada à espectrometria de massa (HS-SPME-GC-MS) foi desenvolvido e aplicado em amostras de cerveja brasileira. As extrações foram realizadas utilizando a fibra CAR/PDMS (carboxen/polidimetilsiloxano), com 15 minutos de tempo de equilíbrio e 90 minutos de exposição da fibra a $50^{\circ} \mathrm{C}$. O método foi linear na faixa de 0,02 e $4,0 \mu \mathrm{g}$. $\mathrm{L}^{-1}$, com coeficiente de correlação de 0,9994 . Os limites de detecção e quantificação foram 0,01 e $0,02 \mu \mathrm{g} . \mathrm{L}^{-1}$, respectivamente. Foram obtidos $96,5 \%$ de recuperação e $4 \%$ de variação entre replicatas de amostras de cerveja fortificadas com 2,0 $\mu \mathrm{g} \cdot \mathrm{L}^{-1}$ de $(E)$-2-nonenal. O método desenvolvido foi considerado simples, eficiente e altamente sensível para a determinação deste analito, sendo facilmente aplicado no controle de qualidade das cervejarias. $\mathrm{O}(E)$-2-nonenal foi encontrado em todas as amostras de cervejas analisadas com níveis entre 0,17 to $0,42 \mu \mathrm{g} . \mathrm{L}^{-1}$.

Palavras-chave: cerveja; (E)-2-nonenal; off-flavor; compostos voláteis; SPME.

\section{Introduction}

Beer connoisseurs have recognized that the expected flavor is normally the flavor of particularly fresh beer. So, beer aroma substances are very important as they make a major contribution to the quality of the final product. As a result of beer ageing, the composition may change, and the expected flavor is lost (VANDERHAEGEN et al., 2006). Thus, to preserve the sensory stability of beer during ageing has become the most important quality parameter for brewers. Hashimoto (1966) was the first to report a remarkable increase in the level of volatile carbonyls in beer during storage, in parallel with the development of stale flavors. Often, this stale taste is related to cardboard flavor development (VANDERHAEGEN et al., 2006), sweet and toffee notes (GUIDO et al., 2004) or typical onion odor (CALLEMIEN; DASNOY; COLLIN, 2006).

(E)-2-nonenal has received particular attention as the major source of the papery/cardboard flavor developed in aged beers. The pathways that explain the formation of
(E)-2-nonenal during beer storage are still unclear. Ochiai et al. (2003) reported Strecker degradation of amino acids, oxidative degradation of isohumulones, oxidation of fatty acids and aldol condensations, as hypotheses for (E)-2-nonenal formation. Moreover, this compound has an extremely low flavor threshold $\left(0.035 \mu \mathrm{g} . \mathrm{L}^{-1}\right)$ (MEILGAARD, 1993). Whereas $0.2-0.5 \mu \mathrm{g} . \mathrm{L}^{-1}$ is usually detected after $3-5$ months at $20^{\circ} \mathrm{C}$ or after 3-5 days at $40{ }^{\circ} \mathrm{C}$ (LIEGEOIS et al., 2002).

To examine the staling process of beer, these stale-flavor compounds have to be determined not only by sensory analysis, but also by reliable and highly sensitive instrumental analysis (OCHIAI et al., 2003). Several analytical methods for the determination of aldehydes in beer have been reported, such as liquid-liquid extraction, low-pressure or steam distillation or sorbent extraction (LIU; ZENG; XIONG, 2005). However, these methods are rather complicated and not highly selective (VESELY et al., 2003) and most of them produce extracts

${ }^{1}$ Engenharia de Alimentos, Universidade de Campinas - UNICAMP - Cidade Universitária “Zeferino Vaz”, CEP 13081-970 - Campinas - SP, Brasil, e-mail: helena@fea.unicamp.br ${ }^{*}$ A quem a correspondência deve ser enviada 
with a flavor composition that is representative of the liquid matrix and not of the headspace. Chromatographic signals of trace substances may be obscured by high concentrations of low-volatile compound (LIU; ZENG; XIONG, 2005). So, the majority of the procedures involve preconcentration followed by a derivatization step and separation by HPLC or GC. Derivatization of the carbonyls is an additional step, effective in decreasing the interference caused by the beer matrix (VANDERHAEGEN et al., 2006). On the other hand, it is an additional step to control in the analysis.

Solid-phase microextraction (SPME) was introduced in 1990 (ARTHUR; PAWLISZYN, 1990) as a simple, fast, reliable and solvent-free extraction technique. The technique is based on partitioning the analytes between the matrix and the fiber coating (direct extraction), or between the gas phase above the sample and the SPME fiber (headspace extraction) (KOWALSKI et al., 2007). The use of HS-SPME in beer analysis has been mainly focused on research of the off-flavors, such as sulfur compounds (HILL; SMITH, 2000) and carbonyl compounds (VESELY et al., 2003). Mejías et al. (2002) evaluated the efficiency of four different fibers (PDMS, carboxenpolydimethylsiloxane - CAR-PDMS, carbowax-divinylbenzene - CW-DVB and polydimethylsiloxane-divinylbenzene - PDMSDVB) on the extraction of volatile compounds in vinegar, and the authors concluded that the efficiency was better for CAR-PDMS fiber. In the same way, Pinho et al. (2006) studied the performance of three different fibers (polyacrylate - PA, PDMS and CAR-PDMS) in beer samples. The most complete profile of beer volatile compounds corresponds to analysis carried out with CAR-PDMS fiber, which extracted more than 102 compounds. Kataoka, Lord and Pawliszyn (2000) related that CAR-PDMS $(75 \mu \mathrm{m})$ phase is a porous material resulting from a mixture of PDMS and CAR that increases retention capacity due to the mutually potentiating effect of adsorption and distribution within the stationary phase.

Just as in other extraction techniques, derivatization is present in SPME. Vesely (2003) obtained good results using SPME with on-fiber derivatization using the derivatization agent $O$-(2,3,4,5,6-pentafluorobenzyl)-hydroxylamine (PFBOA). Ochiai et al. (2003) used a stir-bar sorptive extraction (SBSE) with in-situ derivatization to analyze stale-flavor carbonyl compounds in beer using thermal desorption-gas chromatography-mass spectrometry. However, the possibility of decreasing the extractions step while keeping the same efficiency is a good way to simplify the analysis. Therefore, the aim of this work was to develop a simple method for determination of (E)-2-nonenal in beer without the step of derivatization using HS-SPME. Also, the content of (E)-2-nonenal in some types of commercial Brazilian beers was studied.

\section{Materials and methods}

\subsection{Reagents, standard and samples}

The (E)-2-nonenal was purchased from Sigma-Aldrich (Milwaukee, WI). Water used was previously purified in a Milli-Q system (Millipore, USA), chromatographic grade ethanol used was from TEDIA (USA) and o-phosphoric acid was purchased from ECIBRA (Brazil). An SPME device (Supelco, Bellefonte, PA, USA) containing a fused-silica fiber (10 mm length) coated with a $75 \mu \mathrm{m}$ layer of CAR-PDMS was used. The beer samples (pilsner) were obtained from three different local markets (Campinas, SP, Brazil). All the samples had been produced within the previous 30 days. The study was conducted with 5 brands and 3 lots of each brand, since each lot was formed by the whole content of three canned beers. The samples were identified as RS (non-alcoholic), RE (5.5\% alcohol), RH (5.0\% alcohol) from the same manufacturer, $\mathrm{RO}$ and RK (5.0\% alcohol) from the others manufacturers.

\subsection{Method validation}

The validation parameters consisted in extraction optimization, linearity range, precision, accuracy and limits of detection and quantification. The parameters were carried out in a 5\% ethanol ( $\mathrm{pH} 4.5$ with o-phosphoric acid) solution, except the precision and accuracy that was undertaken in beer. The extraction optimization was carried out with an ethanol solution spiked with $2 \mu \mathrm{g} . \mathrm{L}^{-1}$ of $(E)$-2-nonenal at $50{ }^{\circ} \mathrm{C}$ during $15,30,60,90$ and 120 minutes. Linearity range was evaluated by the external calibration curve with 5 points $(0.02,0.2,1,2$ and $\left.4 \mu \mathrm{g} . \mathrm{L}^{-1}\right)$. The precision involved repeatability ( 8 successive extractions/injections) and the accuracy was achieved by recovery rate by spiking $2 \mu \mathrm{g}$. $\mathrm{L}^{-1}$ of $(E)$-2-nonenal in beer $(\mathrm{n}=3$, in duplicate). The detection and quantification limits were the minimal concentration of the analyte that the peak height was three times and six times the noise base line, respectively.

\subsection{Preparation of the samples}

For each sample three canned beers from the same lot were used which were homogenized and submitted to ultrasound for 1 minute to partially remove gas. An aliquot of $10 \mathrm{~mL}$ of degasified beer was placed into a $23 \mathrm{~mL}$ headspace vial and sealed with a PTFE-faced silicone septum. The analyses were carried out in duplicate.

\subsection{SPME procedure}

The extractions were carried out in a commercially available CAR/PDMS - $75 \mu \mathrm{m}$ fiber. To get the equilibrium between phases, the sample remained for 15 minutes at $50{ }^{\circ} \mathrm{C}$ (with agitation). SPME was performed by inserting the holder into the septum of the vial, and depressing the plunger of the fiber holder so that the fiber was exposed to the sample headspace between 90 minutes with agitation, followed by 10 minutes of desorption. Between each chromatogram blank fiber was used to verify the carryover.

\subsection{Gas chromatographic analysis coupled to mass spectrometry}

The analyses were carried out in a Shimadzu 17A gas chromatograph coupled with a Shimadzu QP-5000 quadrupole mass spectrometer. Desorption proceeded in the injection port of the gas chromatograph (GC) for 2 minutes at $280{ }^{\circ} \mathrm{C}$ with the purge valve off (splitless mode). The compounds 
were separated in a DB-5 fused silica capillary column $30 \mathrm{~m} \times 0.25 \mathrm{~mm}$ i.d. $\times 0.25 \mu \mathrm{m}$ film thickness (J\&W Scientific). The oven temperature program used was 60 to $100{ }^{\circ} \mathrm{C}$ at $3{ }^{\circ} \mathrm{C} /$ minute then raised by $10^{\circ} \mathrm{C} /$ minute up to $250^{\circ} \mathrm{C}$. The final temperature was held for 7 minutes. Helium was the carrier gas at a flow rate of $1.0 \mathrm{~mL} /$ minute. The GC mass spectrometer interface was maintained at $240{ }^{\circ} \mathrm{C}$. Compound identification was realized by comparison of the mass spectrum between standard and sample at the same retention time. To these the single-ion monitoring (SIM) mode chromatogram $(55,70,83$, 96, 111 e $122 \mathrm{~m} / \mathrm{z}$ ) was applied.

\subsection{Statistical analysis}

The data obtained from the beer experiments were analyzed using ANOVA/Tukey $(p<0.05)$. The statistical package used was Statistica ${ }^{\mathrm{TM}} 6.0$ data analysis software by Statsoft, Inc, Tulsa, OK, USA (2001).

\section{Results and discussion}

\subsection{Optimization of HS-SPME conditions}

As described in a previous work, to achieve reproducible results it is essential to keep the samples at constant temperature during equilibrium and exposure time (PINHO; PERES; FERREIRA, 2003). Reineccus (1990) also reported the risk of artifacts production through the Maillard reaction due to excessive heating. Therefore, 15 minutes of equilibrium time and $50^{\circ} \mathrm{C}$ of extraction temperature were used in this work. However, the extraction time was studied between 15 and 120 minutes of extraction. Figure 1 shows the time extraction optimization for (E)-2-nonenal. The results showed that with 15 to 60 minutes of extraction a linear increase was observed, and the equilibrium was verified at 90 minutes, therefore, subsequently extractions were conducted with 90 minutes. Keszler and Héberger (1999) evaluated the influence of extraction parameters on efficiency of SPME in aldehydes analysis. The authors reported that immersion had lower values than $\mathrm{HS}$ and exposure time of 30 minutes at $40{ }^{\circ} \mathrm{C}$ was found to be the optimal condition. Vesely et al., (2003) evaluated the content of 9 aldehydes in beer, and found that the optimal derivatization/extraction condition was 90 minutes at $50^{\circ} \mathrm{C}$, in addition, the salt addition did not have any effect.

\subsection{Method validation}

High correlation was found in the range tested $\left(r^{2}=0.9994\right)$ and the precision parameter showed the RSD (relative standard deviation) of $4 \%$. These values are in agreement with Horwitz, Kamps and Boyer (1980). The limit of detection $\left(0.01 \mu \mathrm{g} . \mathrm{L}^{-1}\right)$ and limit of quantification $\left(0.02 \mu \mathrm{g} . \mathrm{L}^{-1}\right)$ indicated high sensitivity of the system. The method showed high accuracy since the recovery rate was $96.5 \%$. Ochiai et al. (2003) used a stir-bar sorptive extraction (SBSE - $47 \mu \mathrm{L}$ of PDMS) with in-situ derivatization to analyze (E)-2-nonenal, the validate method showed good linearity $\left(\mathrm{r}^{2}=0.9993\right)$, recovery of $99 \%$ and detection limit (LOD) of $0.023 \mu \mathrm{g} . \mathrm{L}^{-1}$. Vesely et al. (2003) using a SPME (PDMS/DVB - $65 \mu \mathrm{m}$ ) with on-fiber derivatization, for (E)-2-nonenal analysis, found $\mathrm{r}^{2}=0.9944,8.0$ and $89 \%$ for linearity, variation coefficient and recovery rate, respectively. So, the results of this study are as good as those cited in the literature with the advantage that the derivatization procedure is not necessary.

\subsection{Sample analysis}

Figure 2 shows a typical beer sample chromatogram. The method showed good resolution and selectivity for (E)-2nonenal. No carryover between analyses was observed.

All samples were obtained with the same validity date and were stored at ambient temperature in the market for around 30 days. Table 1 shows the (E)-2-nonenal amounts in beers. The RO beer showed significantly $(p<0.05)$ higher content of (E)-2-nonenal than the other samples. Otherwise, the RS sample, non-alcoholic beer, presented the lowest value $(p<0.05)$, however, no significant differences in relation to $\mathrm{RH}$ and RE samples were observed (Table 1). In the RS sample, the low value found may be due to the alcohol removal process. Hill and Smith (2000) studied the volatile sulfur compounds

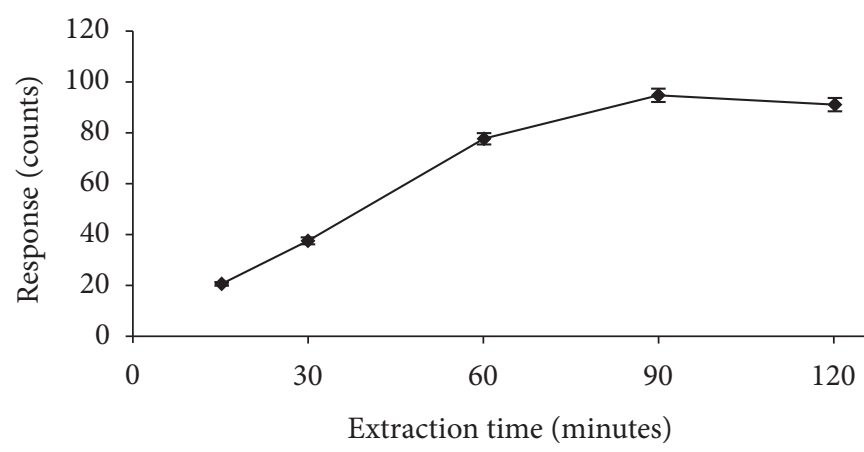

Figure 1. Time extraction optimization to (E)-2-nonenal. The extraction was carried out with CAR-PDMS $(75 \mu \mathrm{m})$ fiber at $50{ }^{\circ} \mathrm{C}$ with 15 minutes of equilibrium time, the ions 55, 70, 83, 96, 111 and $122 \mathrm{~m} / \mathrm{z}$ were monitored via SIM mode. The values presented are the mean of duplicate assays.

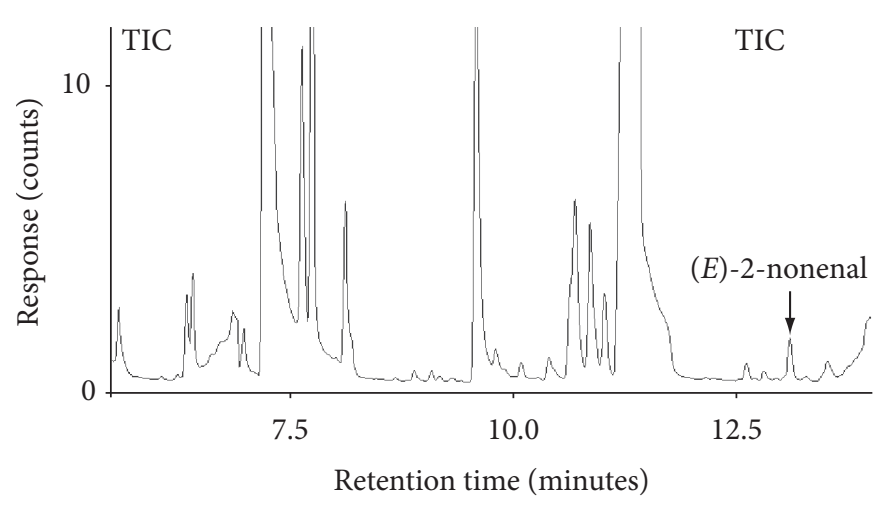

Figure 2. SIM chromatogram obtained by HS-SPME of RO beer sample for (E)-2-nonenal determination. The extraction was carried out with CAR-PDMS $(75 \mu \mathrm{m})$ fiber, 15 minutes of equilibrium time, 90 minutes of extraction at $50{ }^{\circ} \mathrm{C}$. The ions monitored were $55,70,83$, 96,111 and $122 \mathrm{~m} / \mathrm{z}$. 
Table 1. (E)-2-nonenal contents in Brazilian beers.

\begin{tabular}{|c|c|c|}
\hline Sample & Lot & $\mu \mathrm{g} . \mathrm{L}^{-1}($ mean $\pm \mathrm{SD})$ \\
\hline RO & 1 & $0.44 \pm 0.03$ \\
\hline RO & 2 & $0.39 \pm 0.01$ \\
\hline \multirow[t]{2}{*}{ RO } & 3 & $0.44 \pm 0.02$ \\
\hline & Mean $^{*}$ & $0.42^{a} \pm 0.03$ \\
\hline RS & 1 & $0.19 \pm 0.002$ \\
\hline RS & 2 & $0.15 \pm 0.03$ \\
\hline \multirow[t]{2}{*}{ RS } & 3 & $0.17 \pm 0.003$ \\
\hline & Mean $^{*}$ & $0.17^{c} \pm 0.02$ \\
\hline RH & 1 & $0.19 \pm 0.001$ \\
\hline RH & 2 & $0.21 \pm 0.001$ \\
\hline \multirow[t]{2}{*}{ RH } & 3 & $0.20 \pm 0.01$ \\
\hline & Mean $^{*}$ & $0.20^{\mathrm{bc}} \pm 0.01$ \\
\hline RK & 1 & $0.31 \pm 0.004$ \\
\hline RK & 2 & $0.19 \pm 0.01$ \\
\hline \multirow[t]{2}{*}{ RK } & 3 & $0.29 \pm 0.02$ \\
\hline & Mean $^{*}$ & $0.27^{\mathrm{b}} \pm 0.06$ \\
\hline $\mathrm{RE}$ & 1 & $0.19 \pm 0.01$ \\
\hline $\mathrm{RE}$ & 2 & $0.23 \pm 0.02$ \\
\hline \multirow[t]{2}{*}{$\mathrm{RE}$} & 3 & $0.26 \pm 0.01$ \\
\hline & Mean $^{*}$ & $0.23^{b c} \pm 0.03$ \\
\hline
\end{tabular}

${ }^{*}$ Mean of three lots. Different letters corresponding to significant difference $(p<0.05)$. SD: Standard deviation.

in various European beers, including non-alcoholic beer, and the results showed that non-alcoholic beer presented the lowest values for the sulfur compounds, and that the compounds are also removed in the vacuum distillation process. In addition, the vacuum distillation had been used for extraction of carbonyl compounds (LERMUSIEAU et al., 1999). The results of the present work are similar to Drost (1990), who reported 0.10 to $0.25 \mu \mathrm{g} . \mathrm{L}^{-1}$ of $(E)-2$-nonenal in beer.

The values of (E)-2-nonenal found in the beers analyzed are above to the perception limit $\left(0.035 \mu \mathrm{g} . \mathrm{L}^{-1}\right)$ (MEILGAARD, 1993). This could be explained by the storage temperature of the samples in the market, which may favor the reaction mechanisms of the formation of (E)-2-nonenal, once the temperature is not controlled; in addition, as was stated before, through storage, flavor appears to deteriorate greatly with time at a rate depending on beer composition ( $\mathrm{pH}$, oxygen, antioxidants, precursor concentrations, etc.) and storage conditions (packaging, light, etc). A previous study reported that the storage temperature could influence (E)-2-nonenal formation. Vesely et al. (2003) reported that (E)-2-nonenal content after 12 weeks of storage at $0{ }^{\circ} \mathrm{C}$ was $0.01 \mu \mathrm{g} . \mathrm{L}^{-1}$, and at $30{ }^{\circ} \mathrm{C}$ the content increased three times. In agreement, Techakriengkrai, Paterson and Taidi, (2006) related that the content of (E)-2-nonenal was double when the temperature was increased by 4 to $37^{\circ} \mathrm{C}$ in 28 days. Furthermore, only a few days at $38^{\circ} \mathrm{C}$ is sufficient to increase the concentration of the aldehyde above flavor threshold (HAMBRAEUS; NYBERG, 2005).

\section{Conclusions}

A HS-SPME-GC-MS new method was developed and validated for the determination of (E)-2-nonenal in beer samples. CAR-PDMS fiber showed a good response to this compound, even without derivatization. The best extraction condition was 90 minutes of extraction at $50{ }^{\circ} \mathrm{C}$ with agitation. The validation parameters available showed that the method was efficient and highly sensitive, with quantification limit below the threshold. In addition, the method proved to be simple to carry out and it could be used in routine analysis for (E)-2-nonenal, such as quality control of beers. The method was applied using Brazilian beer samples which presented amounts between 0.17 to $0.42 \mu \mathrm{g} . \mathrm{L}^{-1}$ of $(E)-2$-nonenal.

\section{References}

ARTHUR, C. L.; PAWLISZYN, J. Solid phase microextraction with thermal desorption using fused silica optical fibers. Analytical Chemistry, v. 62, n. 19, p. 2145-2148, 1990.

CALLEMIEM, D.; DASNOY, S.; COLLIN, S. Identification of a stale-beer-like odorant in extracts of naturally aged beer. Journal Agricultural Food Chemistry, v. 54, n. 4, p. 1409-1413, 2006.

DROST, B. W. et al. Flavor stability. Journal. American Society Brewing Chemistry, v. 48, n. 2, p. 124-131, 1990.

GUIDO, L. F. et al. Simultaneous determination of E-2-nonenal and $\beta$-damascenone in beer by reversed-phase liquid chromatography with UV detection. Journal of Chromatography A, v. 1032, n. 1, p. 17-22, 2004.

HAMBRAEUS, G.; NYBERG, N. Enzymatic Hydrogenation of trans2-Nonenal in Barley. Journal Agricultural Food Chemistry, v. 53, n. 22, p. 8714-8721, 2005.

HASHIMOTO, N. Research Laboratories of the Kirin Brewery Company. Tokyo: Kirin Brewery Company, 1966. (v. 9, n. 1)

HILL, P. G.; SMITH, R. M. Determination of sulphur compounds in beer using headspace solid-phase microextraction and gas chromatographic analysis with pulsed flame photometric detection. Journal of Chromatography A, v. 872, n. 1, p. 203-213, 2000.

HORWITZ, W.; KAMPS, L. R.; BOYER, K. W. Quality assurance in the analysis of foods for traces constituents. Quality Control, v. 63, n. 4, p. 1344-1347, 1980.

KATAOKA, H.; LORD, H. L.; PAWLISZYN, J. J. Applications of solidphase microextraction in food analysis. Journal of Chromatography A, v. 880, n. 1, p. 35-62, 2000.

KESZLER, A.; HEBERGER, K. Influence of extraction parameters and medium on efficiency of solid-phase microextraction sampling in analysis of aliphatic aldehydes. Journal of Chromatography A, v. 845 , n. 2, p. 337-347, 1999.

KOWALSKI, C. H. et al. Neuro-genetic multioptimization of the determination of polychlorinated biphenyl congeners in human milk by headspace solid phase microextraction coupled to gas chromatography with electron capture detection. Analytical Chimia Acta, v. 585, n. 1, p. 66-75, 2007.

LERMUSIEAU, G. et al. A non-oxidative mechanism for the development of trans-2-nonenal in beer. Journal. American Society Brewing Chemistry, v. 57, n. 26, p. 29-33, 1999.

LIEGEOIS, C. et al. Release of Deuterated (E)-2-Nonenal during beer aging from labeled precursors synthesized before boiling. Journal Agricultural Food Chemistry, v. 50, n. 26, p. 7634-7638, 2002. 
LIU, M.; ZENG, Z.; XIONG, B. Preparation of novel solid-phase microextraction fibers by sol-gel technology for headspace solidphase microextraction-gas chromatographic analysis of aroma compounds in beer. Journal of Chromatography A, v. 1065, n. 2, p. 287-299, 2005.

MEILGAARD, M. C. Individual differences in sensory threshold for aroma chemicals added to beer. Food Quality Preferences, v. 4, n. 3, p. 153-167, 1993.

MEJÍAS, R. C. et al. Optimisation of headspace solid-phase microextraction for analysis of aromatic compounds in vinegar. Journal of Chromatography A, v. 953, n. 1, p. 7-15, 2002.

OCHIAI, N. et al. Determination of stale-flavor carbonyl compounds in beer by stir bar sorptive extraction with in-situ derivatization and thermal desorption-gas chromatography-mass spectrometry. Journal of Chromatography A, v. 986, n. 1 p. 101-110, 2003.

PINHO, O.; FERREIRA, I. M. P. L. V. O.; SANTOS, L. H. M. L. M. Method optimization by solid-phase microextraction in combination with gas chromatography with mass spectrometry for analysis of beer volatile fraction. Journal of Chromatography A, v. 1121, n. 2, p. 145-153, 2006.
PINHO, O.; PERES, C.; FERREIRA, I. M. P. L. V. O. Solid-phase microextraction of volatile compounds in "Terrincho" ewe cheese: comparison of different fibers. Journal of Chromatography A, v. 1011, n. 1, p. 1-9, 2003.

REINECCIUS, G. A. The influence of Maillard reaction on the sensory properties of food. In: AESCHBACHER, H. U.; HURREL, R. F.; LIARDON, R. (Eds.). The Maillard reaction in food processing, human nutrition and physiology. Basel: Birkhauser Verlag, 1990.

STATSOFT. Statistica 6.0. Tulsa, 2001.

TECHAKRIENGKRAI, I.; PATERSON, A.; TAIDI, B. Relationship of sensory staleness in two lagers to headspace concentrations of trans2-nonenal and three staling aldehydes. Journal Institute Brewing, v. 112, n. 1, p. 36-41, 2006.

VANDERHAEGEN, P. et al. The chemistry of beer aging: a critical review. Food Chemistry, v. 95, n. 3, p. 357-381, 2006.

VESELY, P. et al. Analysis of aldehydes in beer using solidphase microextraction with on-fiber derivatization and gas chromatography/mass spectrometry. Journal Agricultural Food Chemistry, v. 51, n. 24, p. 6941-6944, 2003. 